•综述・

\title{
云南省生物多样性保护进展、成效与前瞻
}

\author{
刘春晖 ${ }^{1}$ ，杨京彪 ${ }^{1}$ ，尹仑四2*
}

1. 中央民族大学生命与环境科学学院, 北京 100081; 2. 西南林业大学西南生态文明研究中心, 昆明 650233

摘要: 《生物多样性公约》第十五次缔约方大会(COP15)计划于2021年在云南昆明召开, 大会将评估《2011-2020年生物多样 性战略计划》执行情况及实施进展。如能达成协议, 将出台“2020年后全球生物多样性框架”, 作为指导2020年之后全球生物 多样性保护的最新纲领性文件。这是生物多样性保护国际进程的一个里程碑, 也是展现中国以及云南多年来生物多样性保护 成效的重要契机。作为中国生物多样性最为丰富的省份和具有全球意义的生物多样性关键地区之一, 云南在生物多样性保护 方面投入巨大努力, 在全国较早发布省级《生物多样性保护战略与行动计划(2012-2030年)》、开创地方立法先河、率先试点 建设国家公园、较早开展县域生物多样性本底调查与评估研究工作、建立了首个国家级野生生物种质资源库等，在就地保护、 迁地保护、重大生态工程等众多领域都取得显著成效。本文在梳理云南生物多样性保护进展与成就的基础上，对保护成效进 行了评估, 并有针对性地探讨了云南生物多样性保护未来发展方向及重大意义，加强全省农业生物多样性的保护与可持续利 用、发挥跨境生物多样性保护及减贫示范作用、协调发展生物多样性保护与少数民族传统知识保护等方面是云南省生物多样 性保护今后发展的重要方向，同时本文也为进一步促进云南生物多样性保护与管理提供了基础资料，并为COP15提供地方履 约实例。

关键词: 生物多样性公约; 进展; 成效; 生物多样性保护; 传统知识; 云南

刘春晖, 杨京彪, 尹仑 (2021) 云南省生物多样性保护进展、成效与前瞻. 生物多样性, 29, 200-211. doi: 10.17520/biods.2020082.

Liu CH, Yang JB, Yin L (2021) Progress, achievements and prospects of biodiversity protection in Yunnan Province. Biodiversity Science, 29, 200-211. doi: 10.17520/biods.2020082.

\section{Progress, achievements and prospects of biodiversity protection in Yunnan Province}

Chunhui Liu ${ }^{1}$, Jingbiao Yang ${ }^{1}$, Lun Yin ${ }^{(1 *}$

1 College of Life and Environmental Sciences, Minzu University of China, Beijing 100081

2 Center for Ecological Civilization, Southwest Forestry University, Kunming 650233

\begin{abstract}
Background \& Aim: The 15th Conference of the Parties to the Convention on Biological Diversity (COP15) will take place in Kunming, Yunnan Province in 2021. The conference will assess the implementation and progress of the Strategic Plan for Biological Diversity 2011-2020. Once review is complete, the conference participants will produce the Post-2020 Global Biodiversity Framework, which will become a contemporary document to guide the global conservation of biological diversity after 2020. This conference represents a milestone in the international process of biodiversity conservation and provides an important opportunity for Yunnan to demonstrate its practice and achievements in recent years.

Review Results: Yunnan is the most biodiverse province in China, and it is therefore a key area of global biodiversity significance. Yunnan has also put great effort into biodiversity conservation, including the following achievements: the provincial Biodiversity Strategy and Action Plan (2012-2030) was one of the first issued in the country; became the first province to enact local legislation on biodiversity conservation; took the lead in the construction of national parks; carried out the evaluation of inventory of county-level biodiversity; and established the first national wildlife
\end{abstract}

收稿日期: 2020-03-06; 接受日期: 2020-06-11

基金项目: 云南省哲学社会科学规划重大项目“云南生物多样性保护法治实践经验研究”(ZDZB201906); 生态环境部生物多样性调查评估项目 (2019HJ2096001006)和生态环境部生物多样性调查、观测和评估项目(2019-2023年)

* 通讯作者 Author for correspondence. E-mail: 13888267735@163.com 
germplasm resource bank. Additional significant achievements have been made in in situ conservation, ex situ conservation, and major ecological protection projects.

Perspectives: To provide basic information for biodiversity conservation in Yunnan, and local implementation examples for COP15, we will assess the progress of biodiversity conservation of Yunnan, evaluate the conservation effects, consider future development directions, and explore the significance of biodiversity in Yunnan. What's more, we point out that the conservation and sustainable use of agricultural biodiversity in Yunnan, the demonstration role of cross-border biodiversity conservation and poverty reduction, and the coordinated development of biodiversity conservation and traditional knowledge protection of ethnic minorities are important directions for the future development of biodiversity conservation in Yunnan Province.

Key words: Convention on Biological Diversity (CBD); progress; achievements; biodiversity conservation; traditional knowledge; Yunnan Province

生物多样性是人类社会赖以生存和发展的基 石, 是生态文明水平的重要标志之一(Mckinnon et $\mathrm{al}, 2016)$ 。作为国家战略, 生物多样性保护关系到经 济社会发展全局, 关系到当代及人类未来福祉, 对 于践行绿色发展理念、建设美丽中国具有重要意 义。云南省位于中国西南, 与缅甸、越南和老挝接 壤, 是中国生物多样性最为丰富的省份, 也是世界 相同纬度上生物多样性最丰富的地区(朱华, 2018), 并涉及全球36个生物多样性热点地区中的三个地 区(Cai et al, 2019; CEPF, 2020), 在中国乃至全球的 生物多样性保护中具有十分重要的战略地位。新中 国成立70年来, 云南省在实践中不断摸索生物多样 性保护路径, 通过出台一系列政策法规、制定相关 规划和实施生态工程等措施, 在物种多样性、遗传 多样性及生态系统多样性的保护方面取得了显著 成效。

《生物多样性公约》(以下简称《公约》)于 1992 年通过, 是国际上第一个针对生物多样性保护和利 用的公约, 备受国内外关注(马克平, 2011)。中国是 《公约》最早的缔约国之一, 在履约方面做了大量 卓有成效的工作, 云南作为中国的一个地方省份, 是中国生物多样性保护的一个缩影, 在生物多样性 保护方面进行了大量实践并取得显著成效, 为中国 履行《公约》作出了积极贡献。《公约》第十五次 缔约方大会(COP15)计划2021年在云南省昆明召开, 届时将审议“2020年后全球生物多样性框架”并制定 2021-2030年全球生物多样性保护战略(刘文静等, 2018)。举办这次具有重要里程碑意义的大会, 既体 现了国际社会对中国取得的生物多样性保护成效 的认可, 又显示了云南省在中国生物多样性保护工 作中的重要地位。在此背景下, 期望本文内容能够
为COP15提供地方履约经验和案例支持。

\section{1 云南省生物多样性及其保护意义}

云南省独特、多样的自然环境条件为各种生物 的起源、演化和繁衍提供了适宜的生境。全省国土 面积 39.4 万 $\mathrm{km}^{2}$, 仅占中国陆域国土面积的 $4.1 \%$, 但拥有丰富的物种资源、遗传资源和复杂多样的生 态系统。物种多样性方面, 《云南省生物物种名录 (2016版)》中记载全省有脊椎动物、高等植物、大 型真菌和地衣共25,434种, 其中高等植物和脊椎动 物物种数在全国占比均超过一半(表1), 并且拥有很 多重点保护物种(表2); 云南蕴藏了大量珍贵的遗 传种质资源, 许多经济价值高、利用范围广的栽培 植物与家养动物都能在云南找到其野生型或近缘 种, 形成了丰富的农业栽培作物、特色经济林木、 观赏花卉、药用植物及畜命品种等遗传种质资源 (郑殿升等, $2013 \mathrm{a}, \mathrm{b}$ ), 其中荞麦、糯玉米、茶树、 园艺植物、药用植物及食用菌遗传资源数量在中国 各省份中均位列首位(刘冬梅等, 2018); 生态系统 多样性方面, 《云南省生态系统名录(2018年)》中记 载, 全省几乎包括了地球上所有的陆地生态系统类 型, 涵盖了从热带到高山冰缘荒漠等各类自然生 态系统。

同时, 云南省是重要的“物种基因库”, 不仅拥 有大量具有经济价值的物种, 还分布有众多子遗 种、特有种和稀有种, 是很多物种的起源和分化中 心之一(吴征镒等, 2005), 也是中国种子植物特有属 的重要分布地区之一, 共拥有 125 个中国种子植物 特有属(冯建孟和朱有勇, 2010), 仅次于四川省(129 属) (李仁伟等, 2001), 占中国种子植物特有属总数 (239属)的52.3\% (吴征镒等, 2011)。《云南省生物物 
表1 云南省物种种数及在中国占比

Table 1 The number of species in Yunnan Province and its proportion in China

\begin{tabular}{|c|c|c|c|c|}
\hline \multicolumn{2}{|l|}{$\begin{array}{l}\text { 类群 } \\
\text { Category }\end{array}$} & $\begin{array}{l}\text { 云南省 } \\
\text { 种数 }^{(1)} \\
\text { Species in } \\
\text { Yunnan }^{(1)}\end{array}$ & $\begin{array}{l}\text { 中国种数 } \\
\text { Species in } \\
\text { China }^{(2)}\end{array}$ & $\begin{array}{l}\text { 占比 } \\
\text { Proportion } \\
(\%)\end{array}$ \\
\hline \multirow{2}{*}{\multicolumn{2}{|c|}{$\begin{array}{l}\text { 脊椎动物哺乳类 Mammals } \\
\text { Vertebrate } \text { 鸟类 Birds }\end{array}$}} & 313 & 673 & 46.5 \\
\hline & & 945 & 1,372 & 68.9 \\
\hline & 两栖类 Amphibians & 189 & 408 & 46.3 \\
\hline & 爬行类 Reptiles & 209 & 461 & 45.3 \\
\hline & 鱼类 Fish & 617 & 1,443 & 42.8 \\
\hline & 总计 Total & 2,273 & 4,357 & 52.2 \\
\hline \multirow{5}{*}{$\begin{array}{l}\text { 高等植物 } \\
\text { Higher } \\
\text { plant }\end{array}$} & 切被子植物 Angiosperm & 15,969 & 29,716 & 53.7 \\
\hline & 裸子植物 Gymnosperm & 127 & 227 & 55.9 \\
\hline & 蕨类植物 Pteridophyte & 1,363 & 2,124 & 64.2 \\
\hline & 苔藓植物 Bryophyte & 1,906 & 3,045 & 62.6 \\
\hline & 总计 Total & 19,365 & 35,112 & 55.2 \\
\hline
\end{tabular}

(1)云南省物种种数参考《云南省生物物种名录(2016版)》; (2)中国 物种种数参考王利松等(2015)和蒋志刚(2016), 其中鱼类指我国内 陆鱼类。

(1) Species of Yunnan refer to Biological Species List of Yunnan Province (2016); (2) Species of China refer to Wang et al (2015) and Jiang (2016), fish mainly refers to the inland fish of China.

表2 云南省国家重点保护野生植物及脊椎动物种数

Table 2 Number of national key preserved wild plants and vertebrates in Yunnan Province

\begin{tabular}{|c|c|c|c|}
\hline \multicolumn{2}{|c|}{$\begin{array}{l}\text { 类群 } \\
\text { Biological group }\end{array}$} & $\begin{array}{l}\text { I 级保护 } \\
\text { First class } \\
\text { protected species }\end{array}$ & $\begin{array}{l}\text { II 级保护 } \\
\text { Second class } \\
\text { protected } \\
\text { species }\end{array}$ \\
\hline \multirow{5}{*}{$\begin{array}{l}\text { 野生植物 } \\
\text { Wild plants }\end{array}$} & 裸子植物 Gymnosperm & 28 & 12 \\
\hline & 被子植物 Angiosperm & 14 & 72 \\
\hline & 大型真菌 Macrofungi & - & 2 \\
\hline & 偋类植物 Pteridophyte & 3 & 22 \\
\hline & 总计 Total & 45 & 108 \\
\hline \multirow{5}{*}{$\begin{array}{l}\text { 脊椎动物 } \\
\text { Vertebrates }\end{array}$} & 鱼类 Fish & 2 & 4 \\
\hline & $\begin{array}{l}\text { 两栖、爬行类 } \\
\text { Amphibians and } \\
\text { Reptiles }\end{array}$ & 3 & 9 \\
\hline & 鸟类 Birds & 26 & 145 \\
\hline & 哺乳类 Mammals & 29 & 24 \\
\hline & 总计 Total & 60 & 182 \\
\hline
\end{tabular}

数据来源: 《云南省生物物种名录(2016版)》。

Data source: Biological Species List of Yunnan Province (2016).

种红色名录(2017版)》记载并评估全省25,451个物种, 其中高等植物 19,333 种, 受威胁的物种有 1,577 种, 占评估物种总数的 $8.16 \%$, 略低于中国高等植物受
威胁物种的占比(10.9\%), 特有物种有 2,716 种，受 威胁率为 $24.67 \%$, 较中国高等植物受威胁率(13.9\%) 高。2,285种脊椎动物中受威胁的有503种，占评估 物种总数的 $22.0 \%$, 与中国脊椎动物受威胁物种占 比(21.4\%)基本持平，特有物种有344种，受威胁率 为 $47.67 \%$, 远高于中国脊椎动物受威胁率(30.6\%) (藏春金等, 2016), 因此后续仍需加大对这些物种的 关注度及研究力度, 尤其是特有种。

此外，云南省民族众多，有着丰富的民族文化 多样性。千百年来，各少数民族的居住、饮食、医 药、风俗与当地的生物多样性息息相关，他们在长 期的生产生活实践中积累了大量生物资源保护利 用的传统知识与技术, 有着丰富的生物多样性保护 内涵，支持并丰富了生物多样性的存在，而当地生 物多样性则又孕育了各民族的文化多样性，成为文 化多样性形成的物质基础(龙春林和裴盛基，2003; 裴盛基, 2011)。

\section{云南省生物多样性保护进展}

多年来，云南省委、省政府高度重视生物多样 性保护工作，并相继成立了云南省生物多样性保护 基金会、云南省生物多样性保护委员会及其专家委 员会，各州(市)也建立了与此相应的工作协调机制， 在各级各部门和社会各界的共同努力下, 积极推动 生物多样性保护, 并取得了显著成效。

\section{1 战略规划统筹推进}

《公约》第6条要求各缔约方“为保护和持续利 用生物多样性制定国家战略、计划或方案”。作为 《公约》的缔约国，中国近几十年来做了大量工作， 于1994年发布了第一版《中国生物多样性保护行动 计划》, 确定了优先保护区域及保护对象。此后, 中 国政府又发布了一系列相关规划和计划，对生物多 样性保护提出了大量明确要求, 相关行业部门也分 别在自然保护区、湿地、禽畜遗传资源保护等领域 发布实施了各项计划, 把主要部门的活动纳入国家 的生物多样性保护行动计划中。在此背景下, 云南 省以“保护优先，规划先行”为原则，也逐步将生物 多样性保护工作纳入各项规划和计划(Box 1)。

\section{2 政策法规保护体系不断完备}

自1973年全国首次环保大会召开后，我国逐步 建立了比较完善的环境保护法律体系, 初步形成了 


\section{Box 1 云南省生物多样性规划实践路径及主要内容}

(1) 2007年启动“七彩云南保护行动计划”后, 推出《云南省生物多样性保护工程规划》, 首次明确了生物多样性保 护与经济发展的关系。

（2）2008-2012年, 相继发布《丽江宣言》《腾冲纲领》《西双版纳约定》, 生物多样性保护范围逐步扩大, 全省生 物多样性保护工作全面推进。同时, 2008年国家林业局确定云南为国家公园建设试点省。

(3) 2009年《云南省国家公园发展规划纲要(2009-2020年)》出台, 明确要形成有云南特色、高水平, 并与国际接 轨的云南国家公园体系。为了加大保护力度, 云南省又先后制定了《云南省极小种群物种拯救保护规划纲要(2010-2020 年)》《云南省生物物种资源保护与利用规划纲要(2011-2020年)》等一系列规划计划, 从不同层面开展生物多样性保护 工作。

(4) 2010年, 《中国生物多样性保护战略与行动计划》印发后, 云南省于2013年在全国较早发布了《云南省生物多 样性保护战略与行动计划(2012-2030年)》, 划定了6 个优先保护区域, 提出了9大保护优先领域、34项保护行动, 为全省 生物多样性保护和可持续利用确定了目标、任务和具体行动。

(5) 2016-2018年, 出台了《云南省实施生物多样性保护重大工程方案(2016-2020年)》《云南省生物多样性保护优 先区域规划(2017-2030年)》《云南省自然保护区发展规划(2017-2025年)》《云南省湿地公园发展规划(2018-2025年)》 等一系列规划并不断加以实施, 保护力度持续加大。

与生物多样性保护相关的法律法规体系。云南省在 贯彻执行国家上位法的同时, 十分重视与生物多样 性保护和管理相关的地方性法制建设(王建华和杨 树人, 2009), 这些法规涉及野生动植物资源保护、 森林及珍稀名贵树种资源保护、生态系统保护等多 个方面, 也包括自然保护区、风景名胜区等多个保护 类型(附录1), 它们与国家层面的相关法律一起, 为 云南省生物多样性保护活动提供明确的法律依据。

2018年出台的《云南省生物多样性保护条例》 (以下简称《条例》), 开创了我国生物多样性保护地 方立法的先河, 这是中国第一部生物多样性保护的 地方性法规, 弥补了以往法律法规通常仅针对某一 方面、保护对象单一、保护范围有限的不足(高正文, 2018), 将监督管理、物种和基因多样性保护、生态 系统多样性保护、公众参与和惠益分享、法律责任 均写入法规(陈悦, 2019)。《条例》的出台, 有利于云 南省生物多样性的保护及法规体系的健全, 对保护 国家生物多样性战略资源具有十分重要的意义。同 时, 云南还针对某些区域独特的生物多样性现状及 问题, 根据宪法和法律的基本原则制定了具有地方 特色的特色性立法, 如针对滇池、抚仙湖等九大高 原湖泊制定的“一湖一法”特色性立法。此外, 基于 不同的民族成分、生态环境、社会文化及生计方式, 云南省各民族形成了一系列独特的生物多样性保 护、生物资源可持续利用与管理的习惯法(薛达元和 郭胨, 2009), 并制定了乡规民约, 是具有一定强制 性的行为规范, 成为了国家政策法规的有益补充。
例如滇西北迪庆藏族自治州境内的白马雪山国家 级自然保护区及周边地区, 神山领地内的所有动植 物都被当地藏民赋予神圣的地位, 禁止破坏(杨立 新等, 2019)。这些传统习惯法虽然未像国家或地方 法律法规由专门机构起草、颁布, 但大部分都对当 地社区起到有效的规范作用, 也促进了当地生物多 样性的保护与可持续利用。

\section{3 生物资源及生物多样性调查与评估}

20世纪80年代, 西南林业大学牵头开展了云南 重要自然保护区综合考察, 基本查清主要保护区的 本底数据及生物多样性资源特征及分布规律(Yang et al，2004)，到2011年完成全省18个自然保护区的 本底调查, 涉及滇南、滇东南、滇西、滇西南、滇 西北、滇东北6个不同的生物地理区。1995年、2009 年国家林业局先后两次启动全国陆生野生动物资 源、全国重点保护野生植物资源调查, 之后云南省 于1997-2001年、2013-2017年间开展了两次野生动 植物资源调查, 基本查清了全省的重点保护野生动 植物的分布、数量及栖息地状况。2010-2012年, 生 态环境部(原环境保护部)组织在滇黔桂三省开展了 县域生物多样性本底调查示范, 针对滇西北18县开 展了县域生物多样性本底综合调查与评估(薛达元 等, 2015), 共调查得到高等植物 48,710种, 脊椎动 物 7,359种, 大型真菌3,604种; 而且特有种比例较 高, 就高等植物而言, 大多数县域特有种比例在 $20 \%$ 左右; 同时调查新增群系记录 22 个(武建勇等, 2016)。通过调查并分析各县物种多样性、特有种、 
珍稀濒危种基本情况及建立数据库, 为保护工作提 供了权威的本底数据, 这也是《公约》第七条(查明 与监测)的基本要求。

云南省的生物多样性编目研究工作走在全国 前列，持续受到国内外生物学家和环保工作者关注， 先后出版了《云南植被》《云南植物志》《云南森林》 《云南鱼类志》《云南两栖爬行动物志》《云南鸟类 志》《云南兽类志》《横断山区维管植物》《西双版 纳高等植物名录》《滇东南有花植物名录》《云南大 百科全书·生态编》等生物多样性基础研究系列专 著。2015-2019年间, 为进一步摸清生物物种本底, 云南省开展了生物物种名录审核、红色名录评估及 生态系统名录评估工作。在中国各省率先发布了

《云南省生物物种名录(2016版)》《云南省生物物种 红色名录(2017版)》《云南省生态系统名录(2018版)》

《云南省外来入侵物种名录(2019版)》, 全面系统地 摸清了全省生态系统、生物物种的基本情况和受威 胁状况, 明确了保护对象, 为生物多样性保护与持 续利用奠定了科学基础(附录2)。

\section{4 就地保护与迁地保护齐头并进}

\subsection{1 就地保护体系类型齐全}

就地保护(in situ conservation)是生物多样性保 护的根本措施，目前中国已建立了自然保护区、风 景名胜区等数量众多、类型丰富、功能多样的各类 自然保护地，在保存自然本底、保护生物多样性、
维护生态系统稳定、改善生态环境质量和保障国家 生态安全等方面发挥了重要作用。初步统计中国目 前已有各类自然保护地约1.18万处，自然保护小区 约5万个(唐小平等, 2019)。云南省已建成以自然保 护区为主体，森林公园、湿地公园、风景名胜区与 世界遗产地等类型为补充的自然保护地体系，面积 约占全省面积的20\% (刘冬梅等，2017), 高于全国 的平均水平 $(18 \%)$, 并提前实现《公约》下 “爱知目 标”设定的到2020年面积达到陆地面积 $17 \%$ 的目标 (银森录和李俊生, 2019)。截至2018年底, 共建立自 然保护区161个、风景名胜区66个、世界自然与文 化遗产地 5 个、国家湿地公园18个、森林公园58个、 国家公园13个、水产种质资源保护区21个，形成布 局合理、类型齐全的就地保护网络体系。这也是云 南省履行《公约》第8条“建立保护区系统或需要采 取特殊措施以保护生物多样性地区”的实际行动。

自然保护区作为云南省生物多样性保护地的 主要类型, 保护类别主要为自然生态系统、野生生 物、自然遗迹三大类(表3), 云南省生态环境厅数据 显示全省自然保护区总面积286万ha，约占全省面 积的 $7.3 \%$, 其中以森林生态系统为主要保护类型, 数量和面积分别占云南省全部自然保护区的 $68.9 \%$ 和 $88.3 \%$, 集中保存了最为原始、完整的森林生态系 统和丰富的生物多样性，特别是国家级自然保护区 对典型生态系统、珍稀濒危物种保护更具潜在价

表3 云南省各类保护区数量及面积情况。数据来源于云南省生态环境厅。

Table 3 Number and area of various nature reserves in Yunnan Province. Data source: Department of Ecology and Environment of Yunnan Province.

\begin{tabular}{|c|c|c|c|c|c|c|c|c|c|c|c|}
\hline \multirow{2}{*}{$\begin{array}{l}\text { 类别 } \\
\text { Category }\end{array}$} & \multirow{2}{*}{$\begin{array}{l}\text { 主要保护类型 } \\
\text { Protection type }\end{array}$} & \multicolumn{2}{|l|}{ 合计 Total } & \multirow{2}{*}{$\begin{array}{l}\text { 国家级 } \\
\text { 数量 } \\
\text { Number }\end{array}$} & \multirow{2}{*}{$\begin{array}{l}\text { National level } \\
\text { 面积 } \\
\text { Area (ha) }\end{array}$} & \multirow{2}{*}{$\begin{array}{l}\text { 省级 } \\
\text { 数量 } \\
\text { Numb }\end{array}$} & \multirow{2}{*}{$\begin{array}{l}\text { Provincial level } \\
\text { 面积 } \\
\text { er Area (ha) }\end{array}$} & \multirow{2}{*}{$\begin{array}{l}\text { 州市级 } \\
\text { 数量 } \\
\text { Number }\end{array}$} & \multirow{2}{*}{$\begin{array}{l}\text { City level } \\
\text { 面积 } \\
\text { Area (ha) }\end{array}$} & \multirow{2}{*}{$\begin{array}{l}\text { 县区级 } \\
\text { 数量 } \\
\text { Number }\end{array}$} & \multirow{2}{*}{$\begin{array}{l}\text { County level } \\
\text { 面积 } \\
\text { rArea (ha) } \\
\end{array}$} \\
\hline & & $\begin{array}{l}\text { 数量 } \\
\text { Number (\%) }\end{array}$ & $\begin{array}{l}\text { 面积 } \\
\text { Area (ha)(\%) }\end{array}$ & & & & & & & & \\
\hline \multirow{3}{*}{$\begin{array}{l}\text { 自然生态系约 } \\
\text { Natural } \\
\text { ecosystems }\end{array}$} & 森林生态系统 & 111 (68.9) & $2,525,859(88.3)$ & 16 & $1,346,861$ & 22 & 599,961 & 39 & 371,380 & 34 & 207,656 \\
\hline & Forest ecosystem & & & & & & & & & & \\
\hline & $\begin{array}{l}\text { 内陆湿地 } \\
\text { Inland wetlands }\end{array}$ & $12(7.5)$ & $141,528(4.9)$ & 1 & 79,700 & 5 & 47,525 & 2 & 1,200 & 4 & 13,103 \\
\hline \multirow[t]{2}{*}{$\begin{array}{l}\text { 野生生物 } \\
\text { Wildlife }\end{array}$} & $\begin{array}{l}\text { 野生动物 } \\
\text { Wild animal }\end{array}$ & 19 (11.8) & 104,675 (3.7) & 4 & 83,133 & 4 & 12,218 & 9 & 8,099 & 2 & 1,224 \\
\hline & $\begin{array}{l}\text { 野生植物 } \\
\text { Wild plants }\end{array}$ & $10(6.2)$ & $70,174(2.5)$ & 0 & 0 & 4 & 15,771 & 2 & 50,202 & 4 & 4,200 \\
\hline \multirow[t]{2}{*}{$\begin{array}{l}\text { 自然遗迹 } \\
\text { Natural sites }\end{array}$} & $\begin{array}{l}\text { 地质遗迹 } \\
\text { Geological relic }\end{array}$ & $7(4.3)$ & $15,315(0.5)$ & 0 & 0 & 2 & 5,290 & 3 & 3,292 & 2 & 6,733 \\
\hline & $\begin{array}{l}\text { 古生物遗迹 } \\
\text { Paleontological } \\
\text { remains }\end{array}$ & $2(1.2)$ & $2,800(0.1)$ & 0 & 0 & 1 & 1,800 & 1 & 1,000 & 0 & 0 \\
\hline 合计 Total & & 161 & $2,860,351$ & 21 & $1,509,695$ & 38 & 682,565 & 56 & 435,173 & 46 & 232,916 \\
\hline
\end{tabular}




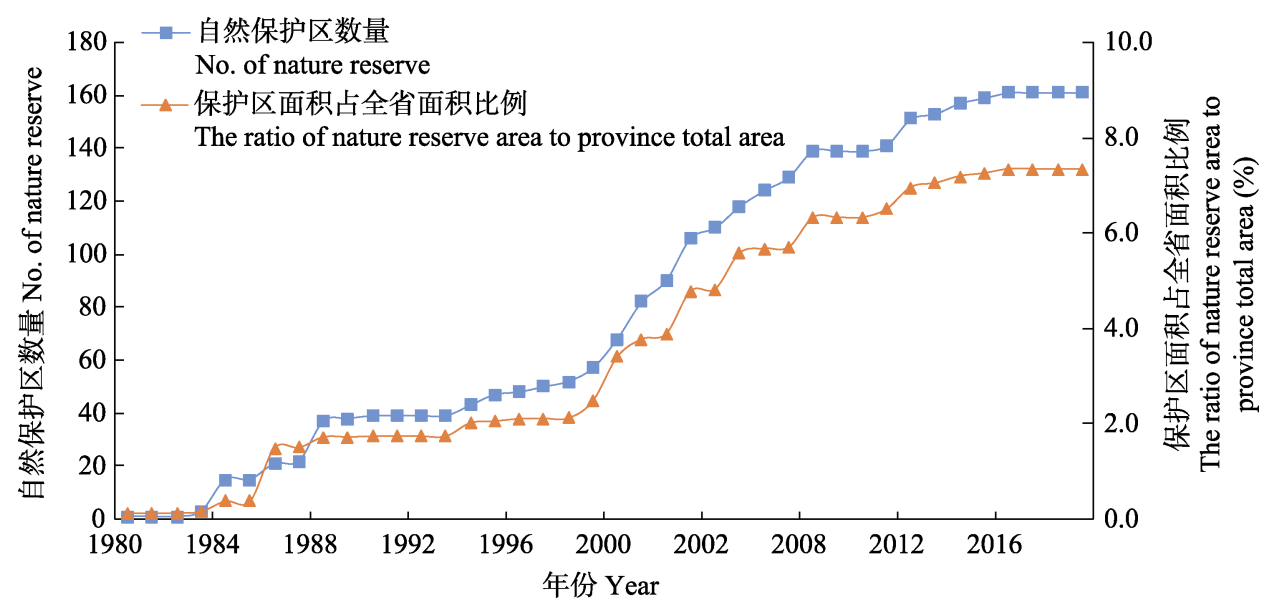

图1 1980-2019年云南省自然保护区数量及面积占比。数据来源于云南省生态环境厅。

Fig.1 The number of nature reserves in Yunnan and proportion of area from 1980 to 2019. Data source: Department of Ecology and Environment of Yunnan Province.

值。采用云南省生态环境厅公布的各自然保护区批 复时间及面积数据, 对近 40 年云南省自然保护区建 设动态进行分析可知(图1), 从20世纪80年代初期至 90年代中期, 全省自然保护区处于始建阶段; 从 1997年发布《云南省自然保护区管理条例》开始, 自 然保护区经历了一个较快速发展阶段, 到2008年数 量增加至139个, 这一阶段是云南省自然保护区全 面规划和迅速建设阶段; 2008年至今, 是保护区科 学规划与经营管理阶段, 数量增幅相对减小, 但更 加注重科学管理, 保护区建设从抢救性建立、数量 和面积规模快速增长阶段进入质量提高阶段(武建勇 等, 2013), 实现由数量规模型向质量效益型的转变。

除建立自然保护区保护外, 云南也是全国率先 试点建设国家公园的省份。1996年借鉴国外经验率 先在国内开展国家公园研究和实践探索; 2008年国 家林业局确定云南为国家公园建设试点省; 2015年 确定云南为国家公园体制试点省。在形成国家公园 建设模式的20余年中, 云南省国家公园探索与实践 工作持续深入, 在科学决策、规范管理、强化监督、 系统规划、立法支撑、社区协调(任治忠, 2018)等方 面都做了大量工作。此外, 云南省也在采取有力措 施全面推进森林公园、湿地公园、风景名胜区与世 界遗产地的建设, 其中昭通大山包、迪庆碧塔海和 纳帕海、丽江拉市海均被《国际湿地公约》列入《国 际重要湿地名录》。目前全省的自然保护体系日渐 丰富完善, 保护范围内的自然环境和生物多样性保 护得到改善。

\subsection{2 迁地保护有序推进}

迁地保护(ex situ conservation)作为就地保护的 补充, 在生物多样性保护方面发挥了重要作用, 尤 其是对于那些失去生存繁育栖息地、在自然环境中 无法保存的物种(Schwartz et al, 2017)。截至2018年, 中国已建立了 200 多个植物园, 收集保存了 20,000 多种植物; 建立了 230 多个动物园和250处野生动物 拯救繁育基地(薛达元和张渊媛, 2019)。云南也已形 成由植物园、树木园、动物园、种质资源库、引种 繁育中心等构成的珍稀濒危野生动植物迁地保护 网络, 并相应开展了部分物种的迁地保护和引种繁 育研究。目前建立的迁地保护机构有中国科学院西 双版纳热带植物园、昆明植物研究所昆明植物园、 丽江高山植物园等十余个大型植物迁地保护场所, 以及动物园、野生动物收容救护中心等动物迁地保 护设施, 以各种方式保存了云南省及我国的珍稀濒 危物种, 并开展了大量的人工驯化、繁育研究工作。

另外, 云南省与中国科学院在2007年共同建成 了中国西南野生生物种质资源库, 这是中国首个国 家级野生生物种质资源库, 也是全球仅有的两个按 国际保存标准建设的野生生物种质库。截至2019年, 共搜集保存种子10,285种82,746份; DNA样品6,804 种 60,450份; 离体材料如试管苗、块根块茎等 2,043 种 24,000份; 引种和驯化的重要野生植物材料437 种45,980份; 珍稀濒危特有的野生脊椎动物种质资 源材料2,154种58,797份; 微生物物种2,260种22,600 份。资源库的建成, 使我国生物战略资源安全得到 可靠保障, 为中国切实履行国际公约、实现生物多 
样性的有效保护和实施可持续发展战略奠定了坚 实基础。

\section{云南省生物多样性保护成效显赫}

3.1 各类生态系统及国家重点保护野生动植物得 到有效保护

经过多年建设, 云南省形成了较为完善的就地 保护体系，使全省 $90 \%$ 以上的典型生态系统和 $85 \%$ 的珍稀濒危野生动植物得到有效保护(刘冬梅等, 2017)。就地保护的主要保护对象有热带和亚热带森 林生态系统、山地苔藓阔叶林生态系统、亚高山针 叶林生态系统、毛竹(Phyllostachys heterocycla)和筇 竹(Qiongzhuea tumidinoda)林生态系统、高原湖泊、 冰山遗迹; 野生动植物包括野生茶树 (Camellia sinensis)、木兰(Magnolia liliflora)、龙血 树(Dracaena angustifolia)、华山松(Pinus armandii)、苏铁(Cycas revoluta)、滇金丝猴(Rhinopithecus bieti)、亚洲象 (Elephas maximus)、黑颈鹤(Grus nigricollis)等(蒋志 刚和马克平, 2017)。根据2017年完成的云南省第二 次重点保护野生植物资源调查统计, 全省就地保护 植物 130 余种, 约占全省重点保护植物的 $85.6 \%$, 与 2008年相比(苑虎等, 2009), 提高了 8.7 个百分点。

近20年来云南省还全面实施了石漠化治理、天 然林保护、重点生态治理修复、退耕还林、湿地保 护与恢复等各项生物多样性保护工程, 促进了退化 生态系统和野生物种生境的恢复, 有效保护了生物 多样性。特别是2018年云南省划定生态保护红线面 积 11.84 万 $\mathrm{km}^{2}$, 占全省国土面积的 $30.9 \%$, 包括了滇 西北、滇西、滇东南、滇南等大批生物多样性保护 重要区域, 将一批已被列入重点保护物种名录但未 被保护地体系覆盖而处于保护空缺的物种纳入保 护范围，使全省约59\%的森林、42\%的灌从、33\%的 草地和59\%的湿地等重要生态系统保护得到加强 (叶胥, 2018)。生态保护红线的划定是对云南生物多 样性保护的重要补充。

\section{2 成功启动了多项极小种群野生植物保护项目}

极小种群野生植物(plant species with extremely small populations, PSESP)是指分布地域狭窄或呈间 断分布, 长期受自身因素限制和外界因素干扰, 呈 现种群退化和数量持续减少、种群及个体数量都极 少, 已经低于稳定存活界限的最小生存种群 (minimum viable population, MVP), 而随时濒临灭 绝的野生植物(孙卫邦, 2013; Meek et al, 2015; Sun, 2016)。2005年，云南省向国家林业局提交了《云南 省特有野生动植物极小种群保护工程项目建议书》, 首次提出极小种群物种保护的概念(杨文忠等, 2015)。2008年，国家林业局、云南省林业厅及中国 科学院昆明植物研究所在昆明联合举行了第一次 全国极小种群野生植物保护研讨会和种群回归自 然启动仪式，这是首次在国家层面开展PSESP保护 工作。2011年，国家林业局与云南省人民政府共同 启动“云南省极小种群野生植物保护试点项目”, 开 展了西畴青冈(Cyclobalanopsis sichourensis)、滇藏 榄(Diploknema yunnanensis)、华盖木(Manglietiastrum sinicum)、云南蓝果树(Nyssa yunnanensis)等植 物的保护工作(Yang et al, 2020)。2012年，国家林业 局制定了《全国极小种群野生植物拯救保护工程规 划(2011-2015年)》，正式启动了我国对极小种群野 生植物的保护和拯救。2016年和2017年，国家重点 研发计划典型脆弱生态修复与保护研究重点专项 项目“典型极小种群野生植物保护与恢复技术研究” 和国家科技基础资源调查专项项目“中国西南地区 极小种群野生植物调查与种质保存” 相继启动, 对 极小种群开展了种群生存力分析、种质资源保存、 就地保护与生境恢复、扩繁、迁地保护和野外回归 6 个方面的研究(蔵润国，2020), 至此我国探索极小 种群野生植物保护的体系逐渐完善。

云南是第一个开展极小种群野生植物保护的 省份，2009-2017年共投入专项资金2,158万元，实 施了 92项保护工程(孙卫邦, 2013; 孙卫邦等, 2019), 包括就地保护的自然保护区、自然保护小区及保护 点的建立，以及迁地保护等工程(云南省林业厅野 生动植物保护与自然保护区管理处, 2016)。2018年, 云南省政府颁布的《云南省生物多样性保护条例》 将极小种群野生物种及其遗传资源的保护作为优 先考虑的内容。目前，全省纳入政府层面保护行动 计划的极小种群野生植物共计87种。截至2017年底, 已经对67种植物进行了就地保护, 80种植物进行了 迁地保护。同时, 开展了26种植物的种群恢复工作 (Sun et al, 2019; Yang et al, 2020)，包括华盖木、西畴 青冈、漾濞槭(Acer yangbiense)、杏黄䛜兰 (Paphiopedilum armeniacum)、巧家五针松(Pinus 
squamata)等(Yang et al, 2020), 极小种群野生植物 繁育人工种群 10 万余株, 回归 30,000 多株(陈勋儒, 2019)。迁地保护的华盖木、滇桐 (Craigia yunnanensis)、云南金钱槭(Dipteronia dyerana)、荌 翅藤(Calycopteris floribunda)、漾濞槭等已在迁地保 护地开花, 部分种类能正常结实。此外, 还建立了 30 个就地保护区(其中 23 个物种在自然保护区以外) 和18个迁地保护区, 包括 9 个物种的实验田(Yang et $\mathrm{al}, 2020)$, 在中国西南野生生物种质资源库保存了 极小种群野生植物种子20种94份 (陈勋儒, 2019)。

\section{3 与生物多样性保护相关的科研机构和平台建 设加强}

科研平台建设方面, 自20世纪80年代以来云南 各高校及科研院所研究人员就一直在开展生物多 样性研究工作, 奠定了云南省生物多样性研究平台 建设的基础。近年来, 以此为依托相继建立了 “中国 科学院东亚植物多样性与生物地理学重点实验室” “国家林业局云南珍稀濒特森林植物保护和繁育重 点实验室” “云南省森林植物培育与开发利用重点 实验室” “云南省极小种群野生植物综合保护重点 实验室” “云南省生物资源保护与利用国家重点实 验室”等一批省部级生物多样性研究平台, 致力于 解决生物多样性保护、生物资源可持续利用和特色 生物资源发掘中的科学问题和关键技术。另外, 各 科研机构和相关部门也开展了大量相关生物多样 性调查、监测、评估方面的工作, 并建有中国科学 院丽江高山植物园及丽江森林生态系统定位研究 站、元江干热河谷生态站、哀牢山亚热带森林生态 系统研究站等多个与生物多样性保护和监测相关 的野外台站, 在生物多样性监测与科学研究、科普 教育和生态示范等方面发挥了重要作用。

此外, 云南省建成的动植物标本馆, 通过对生 物多样性数据的采集、管理和利用, 为生物多样性 的保护提供了重要的支撑平台。主要标本馆有中国 科学院昆明植物研究所标本馆、中国科学院昆明动 物研究所标本馆、中国科学院西双版纳热带植物园 标本馆、云南大学植物标本馆、云南师范大学生命 科学学院动植物标本室、西南林业大学标本馆、云 南省林业科学院标本室等。

\section{云南省生物多样性保护展望}

经过多年的保护工作, 云南省生物多样性保护
将展开新的一页, 起点更高任务更重。《公约》一直 倡导各缔约方尽可能并酌情建立保护区或采取需 要的措施以保护生物多样性, 基于前期保护工作, 我们建议云南省继续加强解决生物多样性保护空 缺问题, 在保护与拯救珍稀濒危物种及各类生态系 统方面发挥优势。(1)针对分布于滇西北保护区海拔 $2,600-2,800 \mathrm{~m}$ 以上、且处于保护区边缘或较远区域 的物种(田祥宇等, 2015), 需升级现有保护区并扩大 保护范围。(2)对尚未建立自然保护区或未纳入保护 范围的典型生态系统、国家重点保护野生动植物 (Zhang et al, 2012), 申报建立自然保护地或优先保 护小区, 并针对极小种群定期进行野外资源调查和 保育研究。如滇西北的碧罗雪山、香格里拉大峡谷 等区域(王勇等, 2018), 以及集中分布于滇东南地区 古老且特有的极小植物类群莲座葓科, 均处于保护 空缺(王崇云等, 2012; 田祥宇等, 2015)。(3)对于大 型哺乳动物, 保护工作面临的挑战更为严峻, 保护 地建设需要更多的考虑保护面积、廊道连通性及最 大限度减少人为干扰等因素。

此外, 云南省在积极配合中央有序开展《公约》 第十五次缔约方大会(COP15)筹备工作, 倾全省之 力办成一届成功圆满、具有里程碑意义大会的同时, 也需要立足本省实际, 明确未来发展方向, 为全省 生物多样性保护上更高台阶提供实践支撑, 为中国 建设重要的生物多样性宝库做出贡献, 也为全球生 物多样性保护贡献中国智慧和力量。

(1)云南省农业生物多样性丰富, 是全省未来 发展的重要战略资源, 也是云南省生物多样性保护 工作区别于其他省份的特色之一。农业生物多样性 是人类生计的基本保障(Allen et al, 2014), 目前全 球大多数国家都在进行集约化农业以促进经济发 展和提高国民生活水平, 但与之相应的则是农业生 物多样性的不断降低(Emile et al, 2011), 从某种意 义上讲, 加强农业生物多样性的保护与可持续利用 是云南省、中国乃至全球需面对的共同课题。云南 省立足于当下, 重新思考农业生物多样性的保护和 农村未来发展, 继续开展传统资源补充调查评估、 优良品种种质基因鉴定篮选、推广与农作物品种资 源保护利用相关的生产技术、建立生物工程技术中 心或重点实验室、科技转化平台, 实现生物资源的 科学开发和可持续利用, 把发展对生物多样性的影 响降到最低(杨宇明等, 2017), 其更为长远的意义在 
于保存传统农业的智慧, 保留与城市文化相对应的 传统文明，对当地的百姓生计、社会进步和文化传 承起重要作用, 也对全球农业生物多样性保护起示 范性作用。

(2)在跨境生物多样性保护及减贫示范方面发 挥优势和作用。云南省生物多样性热点集中分布于 边境地区(杨宇明等, 2017), 许多珍稀濒危动物跨境 而居, 边境线遍布动物迁徙廊道。继续加强与邻国 建立跨境保护区域, 研究建立跨国界自然保护区并 探索联合管理办法, 明确各国管理机制, 制定保护 战略, 使跨境生物多样性保护成为云南省生物多样 性保护工作的另一重要特色; 同时，在“一带一路” 倡议及《一带一路生物多样性与传统知识保护昆明 宣言》框架下, 云南省未来应加强与东盟、南盟、 大湄公河次区域的生物多样性保护交流合作，更将 促进全省生物多样性保护事业发展, 而由于其区位 优势条件，云南也将为中国与“一带一路”沿线国家 进行生物遗传资源合作交流、贸易等提供有利条件 (刘冬梅等, 2018)。从另一个角度看, 跨境生物多样 性富集的区域往往经济发展相对其他区域缓慢，例 如我国生物多样性保护优先区域涉及的县(市、区) 中，国家级贫困县所占比例达到38\%左右(张丽荣等, 2019), 因此因地制宜开展生物多样性保护与减贫 示范项目以及试点建设, 从替代生计、特色生物资 源利用与发展、生态旅游、生态移民及绿色考评机 制(张丽荣等, 2019)等方面形成推动云南省经济发 展、改善部分区域经济落后的经验模式。

(3)促进生物多样性保护与少数民族传统知识 保护的协同发展。《公约》第10(c)条指出, “保护并 鼓励那些按照传统文化惯例而且符合保护或可持 续利用要求的生物资源习惯使用方式”。因此需要 充分保护这些与生物多样性保护和生物资源可持 续利用相关的传统知识, 将其作为生物多样性保护 的重要内容: (1)利用生物学、生态学、民族学的调 查方法将生物多样性调查与少数民族传统文化和 传统知识调查结合起来, 挖掘生物多样性的传统保 护和传统利用知识内涵; (2)在开展野生动植物资源 调查的同时，加强对传统农业遗传资源、民族医药 传统知识、生物资源可持续的传统利用技术创新与 生产生活方式、与生物多样性相关的传统文化以及 当地传统地理标志产品开发利用实践的调查与评 估(薛达元和郭泺, 2009), 并对这些传统知识进行整
理、编目、登记, 建立生物多样性相关传统知识数 据库, 进而率先在少数民族地区建立并实施生物遗 传资源及相关传统知识获取与惠益分享制度, 为全 球 “土著及地方社区” (indigenous and local communities, ILCs)建立并实施此制度提供示范。

\section{ORCID}

尹仑 (1D) https://orcid.org/0000-0001-5191-6498

\section{参考文献}

Allen T, Prosperi P, Cogill B, Flichman G (2014) Agricultural biodiversity, social ecological systems and sustainable diets. Proceedings of the Nutrition Society, 73, 498-508.

Cai J, Yu WB, Zhang T, Wang H, Li DZ (2019) China's biodiversity hotspots revisited: A treasure chest for plants. PhytoKeys, 130, 1-24.

CEPF (Critical Ecosystem Partnership Fund) (2020) The biodiversity hotspots. https://www.cepf.net/our-work/ biodiversity-hotspots/hotspots-defined. (accessed on 202004-09)

Chen XR (2019) How to protect so many firsts in Yunnan. China Ecological Civilization, (2), 44-46. (in Chinese) [陈 勋儒 (2019) 云南如何保护了那么多第一. 中国生态文 明, (2), 44-46.]

Chen Y (2019) The significance and value of the Regulations on Biodiversity Protection in Yunnan. Socialist Forum, (1), 50-51. (in Chinese) [陈悦 (2019) 《云南省生物多样性保 护条例》的意义和价值. 社会主义论坛, (1), 50-51.]

Feng JM, Zhu YY (2010) On the genera of seed plants endemic to China in Yunnan. Ecology and Environmental Sciences, 19, 621-625. (in Chinese with English abstract) [冯建孟, 朱有勇 (2010) 云南地区中国种子植物特有属的研究. 生态环境学报, 19, 621-625.]

Frison EA, Cherfas J, Hodgkin T (2011) Agricultural biodiversity is essential for a sustainable improvement in food and nutrition security. Sustainability, 3, 238-253.

Gao ZW (2018) Pioneering in local legislation to protect China's biodiversity resource-A brief analysis of Biodiversity Conservation Regulation of Yunnan Province. Environmental Protection, 46(23), 12-15. (in Chinese) [高 正文 (2018) 开创地方立法先河, 保护我国生物多样性 宝库: 《云南省生物多样性保护条例》解析. 环境保护, 46(23), 12-15.]

Jiang ZG (2016) Assessing the surviving status of vertebrates in China. Biodiversity Science, 24, 495-499. (in Chinese) [蒋志刚 (2016) 中国脊椎动物生存现状研究. 生物多样 性, 24, 495-499.]

Jiang ZG, Ma KP (2017) The state’s will, scientific decision and citizen participation: In memory of the first provincial species red list in China. Biodiversity Science, 25, 794-795. (in Chinese) [蒋志刚, 马克平 (2017) 中国生物多样性保 
护的国家意志、科学决策和公众参与: 第一份省域物种红 色名录研究. 生物多样性, 25, 794-795.]

Li RW, Zhang HD, Yang QP (2001) On the genera and families of spermatophyte endemic to China in Sichuan region. Journal of Wuhan Botanical Research, 19, 113-120. (in Chinese with English abstract) [李仁伟, 张宏达, 杨清 培 (2001) 四川分布的中国种子植物特有科属研究. 武 汉植物研究, 19, 113-120.]

Liu DM, Li JS, Xiao NW (2018) Protection and sustainable utilization of biogenetic resources under the Belt and Road initiative in Yunnan Province. Environment and Sustainable Development, 43(5), 108-111. (in Chinese with English abstract) [刘冬梅, 李俊生, 肖能文 (2018) “一带一路”倡 议下云南生物遗传资源保护与可持续利用. 环境与可持 续发展, 43(5), 108-111.]

Liu DM, Shi JP, Li JS, Xiao NW (2017) Biodiversity conservation measures under the "ecological security barrier" strategy in Yunnan Province. Environment and Sustainable Development, 42(6), 26-29. (in Chinese with English abstract) [刘冬梅, 施济普, 李俊生, 肖能文 (2017) 西南生态安全屏障战略视阈下云南生物多样性保 护对策. 环境与可持续发展, 42(6), 26-29.]

Liu WJ, Xu J, Geng YJ, Tian Y, Yin SL (2018) Progress in negotiations on the Post-2020 Global Biodiversity Framework and suggestions for the Chinese government. Biodiversity Science, 26, 1358-1364. (in Chinese with English abstract) [刘文静, 徐靖, 耿宜佳, 田瑜, 银森录 (2018) “2020年后全球生物多样性框架”的谈判进展以及 对我国的建议. 生物多样性, 26, 1358-1364.]

Long CL, Pei SJ (2003) Culture diversity promotes conservation and application of biological diversity. Acta Botanica Yunnanica, 25(Suppl. XIV), 11-22. (in Chinese with English abstract) [龙春林, 裴盛基 (2003) 文化多样 性促进生物多样性的保护与利用. 云南植物研究, 25(增 刊XIV), 11-22.]

Ma KP (2011) Strategic targets for biodiversity conservation in 2011-2020. Biodiversity Science, 19, 1-2. (in Chinese) [马 克平 (2011) 未来十年的生物多样性保护目标. 生物多 样性, 19, 1-2.]

Management Division of Wildlife Protection and Nature Reserve, Yunnan Forestry Department (2016) Never let a species extinct-Action of species with extremely small populations are rescued in Yunnan. Yunnan Forestry, 37(2), 24-28. (in Chinese) [云南省林业厅野生动植物保护与自 然保护区管理处 (2016) 绝不让一个物种消亡一一云南 极小种群物种拯救在行动. 云南林业, 37(2), 24-28.]

Mckinnon MC, Cheng SH, Dupre S, Edmond J, Garside R, Glew L, Holland MB, Levine E, Masuda YJ, Miller DC, Oliveira I, Revenaz J, Roe D, Shamer S, Wilkie D, Wongbusarakum S, Woodhouse E (2016) What are the effects of nature conservation on human well-being? A systematic map of empirical evidence from developing countries. Environmental Evidence, 5, 1-25.
Meek MH, Wells C, Tomalty KM, Ashander J, Cole EM, Gille DA, Putman BJ, Rose JP, Savoca MS, Yamane L, Hull JM, Rogers DL, Rosenblum EB, Shogren JF, Swaisgood RR, May B (2015) Fear of failure in conservation: The problem and potential solutions to aid conservation of extremely small populations. Biological Conservation, 184, 209-217.

Pei SJ (2011) Traditional culture and biodiversity conservation. Bulletin of Chinese Academy of Sciences, 26, 190-196. (in Chinese with English abstract) [裴盛基 (2011) 民族文化 与生物多样性保护. 中国科学院院刊, 26, 190-196.]

Ren ZZ (2018) Exploration and practice of national park in Yunnan. Forestry Construction, (5), 54-57. (in Chinese) [任 治忠 (2018) 云南国家公园的探索与实践. 林业建设, (5), 54-57.]

Schwartz KR, Parsons ECM, Rockwood L, Wood TC (2017) Integrating in-situ and ex-situ data management processes for biodiversity conservation. Frontiers in Ecology and Evolution, 5, 1-7.

Sun WB (2013) Conserving Plant Species with Extremely Small Populations (PSESP) in Yunnan: Practices and Exploration. Yunnan Science and Technology Press, Kunming. (in Chinese) [孙卫邦 (2013) 云南省极小种群 野生植物保护实践与探索. 云南科技出版社, 昆明.]

Sun WB (2016) Words from the Guest Editor-in-Chief. Plant Diversity, 38, 207-208.

Sun WB, Ma YP, Blackmore S (2019) How a new conservation action concept has accelerated plant conservation in China. Trends in Plant Science, 24, 4-6.

Sun WB, Yang J, Dao ZL (2019) Study and Conservation of Plant Species with Extremely Small Populations (PSESP) in Yunnan Province, China. Science Press, Beijing. (in Chinese) [孙卫邦, 杨静, 刀志灵 (2019) 云南省极小种群 野生植物研究与保护. 科学出版社, 北京.]

Tang XP, Jiang YF, Liu ZL, Chen JZ, Liang BK, Lin C (2019) Top-level design of the natural protected area system in China. Forest Resources Management, (3), 1-7. (in Chinese with English abstract) [唐小平, 蒋亚芳, 刘增力, 陈君帜, 梁兵宽, 萄琛 (2019) 中国自然保护地体系的顶层设计. 林业资源管理, (3), 1-7.]

Tian XY, Chen WH, Yang SX, Hua CL, Zheng JX, Shui YM (2015) A comparison of national key protected wild vascular plants in SE Yunnan and NW Yunnan. Plant Diversity and Resources, 37, 113-128. (in Chinese with English abstract) [田祥宇, 陈文红, 杨世雄, 华朝朗, 郑进烜, 税玉民 (2015) 滇东南和滇西北国家重点保护野生维管植物比较 分析. 植物分类与资源学报, 37, 113-128.]

Wang CY, Yang B, He ZR, Wang HB (2012) Analysis on the geographical distribution characteristics of Angiopteridaceae and its causes in Yungui Plateau and Hengduan Mountains, China. Plant Diversity and Resources, 34, 317-325. (in Chinese with English abstract) [王崇云, 杨斌, 和兆荣, 王 浩波 (2012) 云贵高原及横断山区莲座烣科植物地理分 布特征及其格局成因初探. 植物分类与资源学报, 34, 
317-325.]

Wang JH, Yang SR (2009) Study on Local Legislation System. Sichuan People's Publishing House, Chengdu. (in Chinese) [王建华, 杨树人 (2009) 地方立法制度研究. 四川人民 出版社, 成都.]

Wang LS, Jia Y, Zhang XC, Qin HN (2015) Overview of higher plant diversity in China. Biodiversity Science, 23, 217-224. (in Chinese with English abstract) [王利松, 贾渝, 张宪春, 覃海宁 (2015) 中国高等植物多样性. 生物多样 性, 23, 217-224.]

Wang Y, Yu CY, Yang D, Yang GW, Zheng JX, Cai WJ (2018) Study on conservation gap of natural reserves in Yunnan Province. Forestry Inventory and Planning, 43(4), 55-58, 62. (in Chinese with English abstract) [王勇, 余昌 元, 杨东, 杨国伟, 郑进烜, 蔡文婧 (2018) 云南省自然 保护区保护空缺分析. 林业调查规划, 43(4), 55-58, 62.]

Wu JY, Peng H, Jiang XL, Xue DY, Du F, Han LX, Yang ZL, Shui YM, Liu PG, Yang XJ, Jiang WG, Wang YH, Zhao FW, Dai R (2016) An inventory of county-level biodiversity in Northwest Yunnan. Biodiversity Science, 24, 1414-1420. (in Chinese with English abstract) [武建勇, 彭华, 蒋学龙, 薛达元, 杜凡, 韩联宪, 杨祝良, 税玉民, 刘培贵, 杨晓 君, 江望高, 王跃华, 赵富伟, 戴蓉 (2016) 滇西北县域 生物多样性本底调查与评估. 生物多样性, 24, 1414-1420.]

Wu JY, Xue DY, Zhao FW, Wang YJ (2013) Progress of the study on investigation and conservation of biodiversity in China. Journal of Ecology and Rural Environment, 29, 146-151. (in Chinese with English abstract) [武建勇, 薛达 元, 赵富伟, 王艳杰 (2013) 中国生物多样性调查与保护 研究进展. 生态与农村环境学报, 29, 146-151.]

Wu ZY, Sun H, Zhou ZK, Peng H, Li DZ (2005) Origin and differentiation of endemism in the flora of China. Acta Botanica Yunnanica, 27, 577-604. (in Chinese with English abstract) [吴征镒, 孙航, 周浙昆, 彭华, 李德铢 (2005) 中国植物区系中的特有性及其起源和分化. 云南植物研 究, 27, 577-604.]

Wu ZY, Sun H, Zhou ZK, Li DZ, Peng H (2011) Floristics of Seed Plants from China. Science Press, Beijing. (in Chinese) [吴征镒, 孙航, 周浙昆, 李德铢, 彭华 (2011) 中国种子 植物区系地理. 科学出版社, 北京.]

Xue DY, Guo L (2009) On concepts and protection of traditional knowledge. Biodiversity Science, 17, 135-142. (in Chinese with English abstract) [薛达元, 郭泺 (2009) 论传统知识的概念与保护. 生物多样性, 17, 135-142.]

Xue DY, Wu JY, Zhao FW, Dai R (2015) Evaluation demonstration study on inventory of county-level biodiversity. China Science and Technology Achievements, 16(13), 30-31. (in Chinese) [薛达元, 武建勇, 赵富伟, 戴 蓉 (2015) 县域生物多样性本底调查与评估示范研究. 中国科技成果, 16(13), 30-31.]

Xue DY, Zhang YY (2019) Achievement and outlook of biodiversity conservation in China. Environmental
Protection, 47(17), 38-42. (in Chinese) [薛达元, 张渊媛 (2019) 中国生物多样性保护成效与展望. 环境保护, 47(17), 38-42.]

Yang J, Cai L, Liu DT, Chen G, Joachim G, Sun WB (2020) China's conservation program on Plant Species with Extremely Small Populations (PSESP): Progress and perspectives. Biological Conservation, 244, 108535.

Yang LX, Pei SJ, Zhang Y (2019) Action research on Tibetan sacred nature sites (SNS) conservation in Tibetan community in NW Yunnan. Biodiversity Science, 27, 749-757. (in Chinese with English abstract) [杨立新, 裴盛 基, 张宇 (2019) 滇西北藏区自然圣境与传统文化驱动 下的生物多样性保护. 生物多样性, 27, 749-757.]

Yang WZ, Xiang ZY, Zhang SS, Kang HM, Shi FQ (2015) Plant species with extremely small populations (PSESP) and their significance in China's national plant conservation strategy. Biodiversity Science, 23, 419-425. (in Chinese with English abstract) [杨文忠, 向振勇, 张珊珊, 康洪梅, 史富强 (2015) 极小种群野生植物的概念及其对我国野 生植物保护的影响. 生物多样性, 23, 419-425.]

Yang YM, Tian K, Hao JM, Pei SJ, Yang YX (2004) Biodiversity and biodiversity conservation in Yunnan, China. Biodiversity and Conservation, 13, 813-826.

Yang YM, Wang J, Li HM (2017) Study on Biodiversity Conservation Strategy and Action Plan of Yunnan Province. Science Press, Beijing. (in Chinese) [杨宇明, 王娟, 李吴 民 (2017) 云南省生物多样性保护战略与行动计划研究. 科学出版社, 北京.]

Ye X (2018) Yunnan observed the ecological red line strictly and become the most beautiful province in China. Creation, (7), 66-69. (in Chinese) [叶玺 (2018) 云南: 严守生态红 线, 做中国最美省份. 创造, (7), 66-69.]

Yin SL, Li JS (2019) Actively implementing the CBD and strengthening biodiversity protection. China Environment, (6), 20-23. (in Chinese) [银森录, 李俊生 (2019) 积极履 约, 加强生物多样性保护. 中华环境, (6), 20-23.]

Yuan H, Zhang YB, Qin HN, Liu Y, Yu M (2009) The in situ conservation of state key protected wild plants in national nature reserves in China. Biodiversity Science, 17, 280-287. (in Chinese with English abstract) [苑虎，张殷波，覃海宁， 刘燕, 喻梅 (2009) 中国国家重点保护野生植物的就地 保护现状. 生物多样性, 17, 280-287.]

Zang CX, Cai L, Li JQ, Wu XP, Li XG, Li JS (2016) Preparation of the China Biodiversity Red List and its significance for biodiversity conservation within China. Biodiversity Science, 24, 610-614. (in Chinese with English abstract) [蔵春金金, 蔡蕾, 李佳琦, 吴晓莆, 李晓光, 李俊 生 (2016) 《中国生物多样性红色名录》的制定及其对生 物多样性保护的意义. 生物多样性, 24, 610-614.]

Zang RG (2020) Research progress in Wild Plant with Extremely Small Populations in China. Biodiversity Science, 28, 263-268. (in Chinese) [蔵润国 (2020) 中国极 小种群野生植物保护研究进展. 生物多样性, 28, 
263-268.]

Zhang LR, Wang XH, Li RX, Meng R (2019) Biodiversity conservation for poverty reduction: Models and cases. China Environment, (6), 24-26. (in Chinese) [张丽荣, 王夏晖, 李 若溪, 孟锐 (2019) 生物多样性保护助力减贫: 实践模式 与案例. 中华环境, (6), 24-26.]

Zhang MG, Zhou ZK, Chen WY, Slik JWF, Cannon CH, Raes $N$ (2012) Using species distribution modeling to improve conservation and land use planning of Yunnan, China. Biological Conservation, 153, 257-264.

Zheng DS, Gao AN, Li LH, Liu X (2013a) Wild relatives of agricultural crop in Yunnan Province and its peripheral area. Journal of Plant Genetic Resources, 14, 193-201. (in Chinese with English abstract) [郑殿升, 高爱农, 李立会, 刘旭 (2013a) 云南及周边地区农作物野生近缘植物. 植
物遗传资源学报, 14, 193-201.]

Zheng DS, Li XX, Chen SC, Gao AN, Li LH, Liu X (2013b) Resources of wild vegetable and wild fruit in Yunnan Province and its peripheral area. Journal of Plant Genetic Resources, 14, 985-990. (in Chinese with English abstract) [郑殿升, 李锡香, 陈善春, 高爱农, 李立会, 刘旭 (2013b) 云南及周边地区野菜和野果资源. 植物遗传资 源学报, 14, 985-990.]

Zhu H (2018) Origin and evolution of the flora of Yunnan. Plant Science Journal, 36, 32-37. (in Chinese with English abstract) [朱华 (2018) 云南植物区系的起源与演化. 植 物科学学报, 36, 32-37.]

(责任编委：薛达元 责任编辑：问文杰)

\section{附录 Supplementary Material}

\section{附录1 云南省与生物多样性保护相关的地方法规}

Appendix 1 Local regulations related to biodiversity protection in Yunnan Province http://www.biodiversity-science.net/fileup/PDF/2020082-1.pdf

\section{附录2 云南省发布的与生物多样性保护相关的各类名录}

Appendix 2 Various catalogues related to biodiversity conservation in Yunnan Province http://www.biodiversity-science.net/fileup/PDF/2020082-2.pdf 
刘春晖，杨京彪，尹仑 (2021) 云南省生物多样性保护进展、成效与前瞻. 生物多样性, 2021, 29 (2): 200-211. http://www.biodiversity-science.net/CN/10.17520/biods.2020082

\section{附录1 云南省与生物多样性保护相关的地方法规}

Appendix 1 Local regulations related to biodiversity protection in Yunnan Province

\begin{tabular}{|c|c|c|}
\hline 法规名称 & 立法目的 & 年份 \\
\hline Laws and regulations & Legislative intent & Years \\
\hline 《云南省自然保护区管理条例》 & $\begin{array}{l}\text { 1.保护自然环境和自然资源 } \\
\text { 2.加强自然保护区建设和管理 }\end{array}$ & 1997 \\
\hline 《云南省农业环境保护条例》 & $\begin{array}{l}\text { 1.保护和改善农业生态环境 } \\
\text { 2.促进农业生产的可持续发展 }\end{array}$ & 1997 \\
\hline 《云南省森林条例》 & $\begin{array}{l}\text { 1. 保护、培育和合理利用森林资源 } \\
\text { 2.促进林业发展, 改善生态环境 }\end{array}$ & 2002 \\
\hline 《云南省珍贵树种保护条例》 & 保护、发展和合理利用珍贵树种资源 & 2002修 \\
\hline 《云南省环境保护条例》 & $\begin{array}{l}\text { 1.保护和改善生活与生态环境 } \\
\text { 2.合理保护利用各种自然资源 }\end{array}$ & 2004修 \\
\hline $\begin{array}{l}\text { 《云南省三江并流世界自然遗产地保 } \\
\text { 护条例》 }\end{array}$ & $\begin{array}{l}\text { 有效保护和合理利用三江并流世界自然遗产地 } \\
\text { 资源 }\end{array}$ & 2005 \\
\hline 《云南省林地管理条例》 & $\begin{array}{l}\text { 1.加强林地的保护和管理, 科学合理开发利用林 } \\
\text { 地资源 } \\
\text { 2.提高森林覆盖率促进林业可持续发展 }\end{array}$ & 2010 \\
\hline 《云南省风景名胜区条例》 & $\begin{array}{l}\text { 1.加强对风景名胜区的管理 } \\
\text { 2.保护合理利用风景名胜资源 }\end{array}$ & 2011 \\
\hline 《云南省渔业条例》 & $\begin{array}{l}\text { 加强渔业资源保护和合理利用, 促进渔业可持续 } \\
\text { 发展 }\end{array}$ & 2011 \\
\hline 《云南省湿地保护条例》 & $\begin{array}{l}\text { 1.加强对湿地的保护 } \\
\text { 2.恢复和发挥湿地功能 } \\
\text { 3.促进湿地资源的可持续利用 }\end{array}$ & 2013 \\
\hline 《云南省陆生野生动物保护条例》 & $\begin{array}{l}\text { 1.保护、发展和合理利用野生动物资源 } \\
\text { 2.维护生态平衡 }\end{array}$ & 2014修 \\
\hline 《云南省国家公园管理条例》 & $\begin{array}{l}\text { 1.规范国家公园管理 } \\
\text { 2.保护、利用自然资源 }\end{array}$ & 2015 \\
\hline $\begin{array}{l}\text { 《云南省澄江化石地世界自然遗产保 } \\
\text { 护条例》 }\end{array}$ & 加强澄江化石地世界自然遗产的保护、管理和利 & 2017 \\
\hline 《云南省生物多样性保护条例》 & $\begin{array}{l}\text { 1.保护生物多样性 } \\
\text { 2.保障生态安全, 推进生态文明建设 } \\
\text { 3.促进经济社会可持续发展, 实现人与自然和谐 } \\
\text { 共生 }\end{array}$ & 2018 \\
\hline 《临沧市古茶树保护条例》 & $\begin{array}{l}\text { 1. 有效保护古茶树资源 } \\
\text { 2.规范古茶树的管理活动 } \\
\text { 3.促进古茶树资源持续利用 }\end{array}$ & 2016 \\
\hline 《普洱市古茶树资源保护条例》 & $\begin{array}{l}\text { 1. 有效保护古茶树资源 } \\
\text { 2.规范古茶树的管理活动 } \\
\text { 3.促进古茶树资源持续利用 }\end{array}$ & 2018 \\
\hline $\begin{array}{l}\text { 《云南省西双版纳傣族自治州自然保 } \\
\text { 护区管理条例》 }\end{array}$ & $\begin{array}{l}\text { 1.加强自然环境和自然资源的保护管理 } \\
\text { 2.维护生态平衡, 拯救濒危热带资源 } \\
\text { 3.为科研和生产服务, 造福人类 }\end{array}$ & 2019修 \\
\hline $\begin{array}{l}\text { 《云南省玉龙纳西族自治县拉市海高 } \\
\text { 原湿地保护管理条例》 }\end{array}$ & $\begin{array}{l}\text { 1.加强对高原湿地的保护管理 } \\
\text { 2.维护湿地生态功能和生物多样性 } \\
\text { 3.促进湿地资源可持续利用 }\end{array}$ & 2014修 \\
\hline $\begin{array}{l}\text { 《云南省大理白族自治州苍山保护管 } \\
\text { 理条例》 }\end{array}$ & $\begin{array}{l}\text { 1.加强苍山的保护和管理 } \\
\text { 2.合理利用自然资源和人文资源, 促进生态文明 } \\
\text { 建设与经济社会协调发展 }\end{array}$ & 2019修 \\
\hline $\begin{array}{l}\text { 《云南省大理白族自治州洱海管理条 } \\
\text { 例》 }\end{array}$ & $\begin{array}{l}\text { 1.加强洱海资源的保护管理和合理利用 } \\
\text { 2.促进自治州社会经济持续发展 }\end{array}$ & 1998修 \\
\hline
\end{tabular}


刘春晖，杨京彪，尹仑 (2021) 云南省生物多样性保护进展、成效与前瞻. 生物多样性, 2021, 29 (2): 200-211. http://www.biodiversity-science.net/CN/10.17520/biods.2020082

附录2 云南省发布的与生物多样性保护相关的各类名录

Appendix 2 Various catalogues related to biodiversity conservation in Yunnan Province

\begin{tabular}{|c|c|c|}
\hline 名称 & 主要内容 & 发布意义 \\
\hline Name & Main content & Significance \\
\hline 《云南省生物物种名录(2016)版》 & $\begin{array}{l}\text { 收录了大型真菌、地衣、苔蘚、蕨 } \\
\text { 类、裸子植物、被子植物、鱼类、 } \\
\text { 两栖类、爬行类、鸟类、哺乳类共 } \\
11 \text { 个类群 } 25,434 \text { 个物种。 }\end{array}$ & $\begin{array}{l}\text { 1.丰富完善了云南物种名录; } \\
\text { 2.填补了云南大型真菌和地衣类 } \\
\text { 群的名录空白; } \\
\text { 3.标志着云南成为全国第一个公 } \\
\text { 布生物物种名录的省份, 对保护 } \\
\text { 全省生物多样性具有重要意义。 }\end{array}$ \\
\hline $\begin{array}{l}\text { 《云南省生物物种红色名录 } \\
(2017 \text { 版)》 }\end{array}$ & $\begin{array}{l}\text { 按照灭绝、野外灭绝、区域灭绝、 } \\
\text { 极危、濒危、易危、近危、无危、 } \\
\text { 数据缺乏、不宜评估和不予评估 } \\
\text { 的IUCN地区水平的 } 11 \text { 类红色名 } \\
\text { 录等级对云南省已知野生动植物 } \\
\text { 物种全面系统评估。 }\end{array}$ & $\begin{array}{l}\text { 1. 丰富和完善了《中国生物多样 } \\
\text { 性红色名录》, 填补了大型真菌 } \\
\text { 和地衣红色名录空白; } \\
\text { 2. 预警了物种的生存危机, 推动 } \\
\text { 生物多样性保护与资源合理利用 } \\
\text { 的研究工作; } \\
\text { 3. 为政府部门相关决策提供依 } \\
\text { 据。 }\end{array}$ \\
\hline 《云南省生态系统名录(2018版)》 & $\begin{array}{l}\text { 收录了从热带到高山冰缘荒漠等 } \\
\text { 各类自然生态系统, 共计 } 14 \text { 个植 } \\
\text { 被型 } 38 \text { 个植被亚型 } 474 \text { 个群系。 }\end{array}$ & $\begin{array}{l}\text { 1.迄今最准确、最系统、最权威反 } \\
\text { 映云南生态系统多样性的成果; } \\
\text { 2.全国第一个系统、全面的公开 } \\
\text { 发布的生态系统名录; } \\
\text { 3.更加丰富了云南自然植被类型, } \\
\text { 新增 } 2 \text { 个植被型 } 5 \text { 个植被亚型。 }\end{array}$ \\
\hline $\begin{array}{l}\text { 《云南省外来入侵物种名录 } \\
(2019 \text { 版)》 }\end{array}$ & $\begin{array}{l}\text { 收录了云南省境内发现的偋类植 } \\
\text { 物、被子植物、软体动物、甲壳动 } \\
\text { 物、昆虫、鱼、两栖动物、爬行动 } \\
\text { 物、鸟、哺乳动物等类群的外来入 } \\
\text { 侵物种共计 } 441 \text { 种及 } 4 \text { 变种 (植物 } \\
321 \text { 种 } 4 \text { 变种、动物 } 120 \text { 种)。 }\end{array}$ & $\begin{array}{l}\text { 1.迄今最全面、最准确、最权威反 } \\
\text { 映云南外来入侵种的研究成果; } \\
\text { 2.为今后开展外来入侵物种宣传 } \\
\text { 和教育、监测及预警、研究与防治 } \\
\text { 等提供科学依据; } \\
\text { 3.对加强生物安全管理和生物多 } \\
\text { 样性保护具有重要意义。 }\end{array}$ \\
\hline
\end{tabular}

